Методика наставе

Precise Resort Rügen, Загард, Немачка

jovana.davidovic@yahoo.com

\title{
АНДРИЋ И ЧЕХОВ У НАСТАВИ
}

\begin{abstract}
АПСТРАКТ
Компаративна анализа дела Чехова и Андрића омогућава нову наставну обраду стваралаштва ова два писца. Упознавање ученика са компаративном књижевном анализом уводи их у модерне токове науке о књижевности. Истраживањем библијског подтекста, анализа уводи и методу интертекстуалности. Оваква наставна обрада има за циљ да ученике окрене књизи и тако помогне у превазилажењу кризе читања, засигурно једног од највећих проблема данашњице. Методичка обрада уводи и мултимедијални приступ настави. Упоређивање Чеховљевих и Андрићевих дела пружа могућност да се узајамно осветли лепота и сложеност њиховог дела и иновира настава књижевности. Циљ рада је да прикаже компаративне везе у делима Чехова и Андрића, проширујући тако круг писаца са којима Андрићево дело кореспондира.

Кључне речи: приповетка, есеј, мотив, лик, компаративна метода, интертекстуалност, библијски подтекст, методика наставе, мултимедија.
\end{abstract}

\section{ANDRIĆ AND CHEKOV IN THE TEACHING PROCESS}

\begin{abstract}
A comparative analysis of the works of Chekov and Andrić enables a new methodological approach to the opus of these two authors. When students become familiar with the comparative literary analysis, this allows them to learn about the contemporary literary science. The research of the Biblical subtext introduces the method of intertextuality into the analysis. This methodical approach aims to motivate students to read books and thus overcome the reading crisis, which is surely one of the biggest problems today. The methodical approach introduces multimedia in the classroom. The comparison of Chekhov's and Andrić's works provides an opportunity to illuminate their beauty and complexity and innovate teaching literature.
\end{abstract}


The aim of the paper is to show the comparative links in the stories by Chekhov and Andrić and expand the circle of writers with whom Andrić's work corresponds.

Keywords: short story, essay, motive, character, comparative method, intertextuality, Biblical subtext, teaching methods, multimedia.

\section{1. УВОД}

Милан Ђурчинов у свом раду Андрић и Чехов указао је на „одређене сличности и подударности између поетике Чехова и Андрића”, проширујући тако „круг оних светских писаца са којима Андрићево дело по својим поетичким координатама несумњиво кореспондира" (Ђурчинов 1991: 612). Аутор се том приликом ограничио само на подударности које избијају са страница њихове експлицитне поетике. Овај рад проширује започету анализу, додајући јој методички аспект.

Упоредном анализом приповедака Чехова и Андрића биће обухваћене приповетке из наставних програма за Српски језик како за основну тако и за средњу школу. Осим приповедака, рад ће обухватити и Андрићев есеј $O$ причи и причағу ${ }^{1}$. Предложиће се, такође, и нове приповетке за обраду и тиме заћи у надпрограмски ниво, јер „поред обавезног дела програма, утврђеног као разуман стандард за одређени узраст, своје место у настави треба да добије и изборни део програма, који дозвољава избор и ученицима и наставнику, који зна (и истражује) њихове жеље" (Илић 2011: 16).

Андрићеве и Чеховљеве приповетке ${ }^{2}$ проучаваће се и на основу библијског подтекста. Тако велики свет који су ови писци створили и у њему наизглед обични људи, превазилазе своје обичне судбине, па њихове приче добијају егзистенцијалну тежину.

„Читање усредсређено на проналажење библијског подтекста омогућује понирање у најсуштаственији слој песништва и прозирање његовог универзалног значења [...] Познавати Библију, редовно јој се враћати, пажљиво ишчитавати и откривати значења скривена у причама, стално полазити од свете књиге хришћанства да би се постигао идеал православне

${ }^{1}$ Ово је беседа коју је Иво Андрић изложио на свечаности у Стокхолму 1961. године приликом добијања Нобелове награде.

${ }^{2}$ А. П. Чехов Туга и И. Андрић На други дан Божића. 
духовности - то је исто што и усавршити и довршити човека” (Радуловић 2003: 152).

Стога је оваква анализа усавршавање и довршавање и наставника и ученика, јер „пред сваким од нас стоји задатак оснаживања, бодрења и усавршавања своје личности" (Радуловић 2003: 152).

У средишту рада јесте поређење мушких ликова на основу мотива побуне, страха, опрезности, ситничавости, туге, утехе, детињства, писма, молитве и смрти, као доминантних мотива у изабраним приповеткама, али мотива који често играју важну улогу у животу ученика, било да се везују за њихов свет или свет одраслих, па ће тако добити прилику да повежу прочитано са личним искуством. Иако је задатак анализе да пронађе сличности међу писцима, указаће се и на поједине разлике, понекад и супротности.

Што се тиче методичке обраде она је у духу проблемскостваралачког методичког система, истраживачке методе и групног рада. Осим тога искористиће се и могућности мултимедије у настави. Тиме се подстиче самостални рад ученика и активно учење ${ }^{3}$ : „Са психолошког становишта, учење је акт открића и ученик треба да учествује у стварању знања, а не да буде мала жива енциклопедија" (Петровачки и Штасни 2010: 165). Креативна примена наставних метода „не ствара од ученика пасивног репродуктивца, већ активног саговорника у наставном раду" (Стакић 2002: 53), тј. потребно је да се у први план стави продуктивно вођење ученика, а да се потисне репродуктивно ангажовање, које „води ка нижој врсти знања” (Николић 2009: 281).

\section{2. МОТИВ ПОБУНЕ И СТРАХА (Прича о кмету Симану и Чиновникова смрт)}

Андрићева Прича о кмету Симану је незаобилазно школско штиво (Илић 1999: 25). Представља трећи степеник на „рецепцијском путу ученика кроз Андрићеву бескрајну причу” (Петровачки 2008: 256). Пишући ову

\footnotetext{
${ }^{3}$,Active learning is another name for the theory of teaching that emphasizes the students rather that the teacher [...] The mastery of knowledge that comes from having students be active doers and participants [...] Teacher and students become jointly responsibile for a proces in which all grow. What is important is learning, not teaching [...] Student-centered teaching makes the teacher a facilitator rather than a star" (Showalter 35-36).
} 
приповетку, Андрић је, „за тренутак, оставио стару митску Босну и потражио тему у недавној босанској прошлости" (Илић 1999: 25). У питању је приповетка са изразитом социјалном нотом у којој је Андрић показао своју веру у народ, говорећи о „снази и истрајности нашег човека и народа као колектива" (Петровачки 2008: 258).

У наставне програме за седми разред ушао је само одломак ове приповетке, који говори о сусрету аге Ибраге, који је дошао по своју трећину шљива и кмета Симана који својим кратким и оштрим „Не” (Андрић 2008: 355), стаје у одбрану свих својих предака који су три стотине година аргатовали за аге. Није случајно изостављен Симанов трагичан крај. Овако приповетка зрачи историјским и социјалним оптимизмом, шаље поруку да човек треба да се бори за остварење својих права. Мотив који се том приликом издваја јесте мотив побуне: „Након година ћутања овај Андрићев јунак коначно проговара и из њега избија бујица ријечи, дуго времена потискиваних" (Калезић 2006: 135).

За разлику од Симана који је подигао свој глас у одбрану својих права и права свог народа, Червјаков из Чеховљеве Чиновникове смрти то не чини. Червјакову судбину одређује страх. Чиновникова смрт је комична прича са снажним елементима социјалног реализма: „Чеховљеве приче су комичне што некима од њих не смета (Чиновникова смрт[...]) да поседују жестину социјалног реализма" (Мелетински 1997: 321) .

Уколико би се уместо одломка Приче о кмету Симану, узела цела приповетка, она би се са Чиновниковом смрти могла поредити и по питању трагичне судбине главних јунака. Ако томе додамо и мотив страха и побуне, на крају остаје нерешен резултат, јер и један и други доводе до трагичног краја. Само на први поглед, ово може да унесе ноту песимизма јер: „Прича о кмету Симану говори о трагичној немоћи усамљене кметовске побуне” (Калезић 2006: 134). Међутим, оно што је у оба случаја важно истаћи, то је да у свему треба пронаћи меру. Није лоша ни побуна, није лош ни страх. Уколико има праву меру. Симан је био један од оних појединаца који су „услед вртоглавог осећаја моћи, који им је дат изненадним доласком запада, својим превременим индивудуалним иступањем трајно запечатили своју судбину” (Калезић 2006: 134). Његово страдање почиње јер „ни у речима, ни у поступцима није могао да се заустави” (Калезић 2006: 135). Он је „својим преурањеним поступцима изазвао судар са временом и у томе окршају је 
постао страдалник” (Марковић 2010: 112). С друге стране, Червјаков непотребни страх је све зауставио.

\section{3. МОТИВ ОПРЕЗНОСТИ И СИТНИЧАВОСТИ (Чиновникова смрт и Ђорђе Ђорђевић)}

Када су у питању мотиви опрезности и ситничавости, Чеховљеву приповетку Чиновникова смрт могуће је повезати са Андрићевом приповетком Ђорђе Ђорђевић, која је не налази у наставним програмима.

Приповетке Чиновникова смрт и Ђорђе Ђорђевић на плану тематике повезује савременост и уплив у свет малог човека. Особине главних ликова обе приповетке су ситничавост и пасиван однос према животу. Име главног јунака у Чеховљевој приповеци је Червјаков, што у преводу значи човек је црв, чиме Чехов указује на деградацију човека. Андрић свом јунаку даје име Ђорђе Ђорђевић. У први мах то је неко НН лице, међутим, то име има своју симболику у контексту ове приповетке јер указује на неког ко је кроз живот прошао незапамћен, неко ко је обичан и небитан, јер читава приповетка је „Обичан живот, обичног човека” (Андрић 2008: 534). Чехов такође говори о неком ко је небитан, па стога у наслову уместо властитог имена користи придев изведен од заједничке именице. С једне стране је црв, а с друге безимен, и тиме се остварује јасна интертекстуална веза. Осим тога и избор занимања главног јунака се поклапа - Червјаков је „дивни економ” (Чехов 1990: 236), а Ђорђе „уредан чиновник” (Андрић 2008: 534). Избор епитета није случајан, употребљени су са истом намером.

„Кад одједном [...] У приповеткама се често среће истакнуто ”кад одједном". Писци имају право: живот је тако пун изненађења" (Чехов 1990: 236). Ово засигурно могу бити и Андрићеве речи. Чиновникова смрт је једна епизода из Андрићеве приповетке, један од њених завршетака. С друге стране, Ђорђе Ђорђевић је проширена Чиновникова смрт. Лајтмотив Ђокиног живота јесте реченица коју је наследио од свог деде, чије је и име носио. Та реченица је гласила „Ђоко, пази шта радиш” (Андрић 2008: 534). Осим имена и ове реченице, од деде је наследио и врлину готово до истанчаности развијену, која као таква прелази у ману, праву манију. Опрезност и страх при сваком кораку повезује Ђоку са Червјаковим. Ђока је каже Андрић „изгубио је свој изгубљени живот” (Андрић 2008: 537), а то би се с правом могло рећи и за Чеховљевог јунака. Осим тога, повезује их и 
баналност ситуација које их доводе до краја. Червјаков је кинуо у позоришту на свог надређеног и то га ја изједало попут оног црва у његовом имену, а Ђорђа Ђорђевића је временска прогноза као доказ могућег и доброг предвиђања и његова мисао „да много се може предвидети можда и све” (Андрић 2008: 537), навела да превиди једну степеницу. Андрић и овде сличи Чехову, тј. „његовој тежњи да изабере случајне призоре, који су богати унутрашњом драматиком" (Радуловић 2007: 123). У Чеховљевој прози „незнатни догађаји воде великим и суштинским збивањима, а мали људи расту до неочекиваних размера" (Радуловић 2007: 123).

Чеховљев опис чиновникове смрти је једноставно просто саопштење, готово као чиновнички извештај о смрти једног човека:

„Червјакову се у утроби нешто прекиде. Обневидео и оглувео, он устукну према вратима, изађе на улицу и оде посрћући... Кад је махинално дошао кући, легао је, не скидајући униформу, на диван и...умро" (Чехов 1990: 238).

Андрићева слика смрти је далеко дубља и опширнија. То је слика смрти као слика стварног пада, коме је крај у тами, смртоносног пада:

„Само у сновима има таквих падања. Али у сновима не чека на крају тврд и смртоносан камен, него буђење. А ово, ово је стварни пад који се само једном доживи, а коме је крај у тами. Јер нико од живих не може потпуно и до краја да зна како изгледа и шта је то - смртоносан пад [...] овакви доживљају без сведока остају заувек у тами, као саставни део саме смрти.

А пад траје. Човек осећа да пада [...] и то тако брзо да мисао не може ни да га стигне, а камоли да помогне и спасе [...] Доцкан је. Нема више никога. И последња сијалица угасну [...] Ништа. Цео човек се испуни глувим, безименим и вековечним мраком потпуне несвести”. (Андрић 2008: 537)

\section{4. МЕТОДИЧКИ ПРИСТУП}

Наставна обрада Чеховљеве Чиновникове смрти и Андрићеве Приче o кмету Симану везује се за седми разред основне школе и у духу је опредељења за проблемско-стваралачки методички систем, истраживачку наставну методу и групни рад. Ученици ће бити подељени у три групе (основни, средњи и напредни ниво). Две недеље пре наставне обраде добиће 
истраживачке задатке, како би имали довољно времена да се припреме за истраживање, које је замишљено као двочас.

\section{1. Истраживачки задаци}

\subsection{1. Основни ниво}

Које су ваше асоцијације на страх и побуну?

Пратите мотив побуне у Андрићевој приповеци Прича о кмету Симану.

Пратите мотив страха у Чеховљевој приповеци Чиновникова смрт.

\subsection{2. Средњи ниво}

Прочитајте Андрићеву приповетку Прича о кмету Симану у целини.

Упоредите крај приповедака Прича о кмету Симану И. Андрића и Чиновникове смрти А. П. Чехова.

Размислите о смислу побуне и страха. Одговор потражите у овим приповеткама.

\subsection{3. Напредни ниво}

Прочитајте Андрићеву приповетку Ђорђе Ђорђевић.

Упоредите Андрићев лик Ђорђа Ђорђевића и Чеховљевог чиновника на основу мотива ситничавости и опрезности.

Упоредите трагичан крај оба лика и на основу тога закључите коју поруку нам шаљу ове приповетке.

\section{5. ЧЕХОВЉЕВО И АНДРИЋЕВО ДЕТЕ}

- мотиви: детињство, писмо, молитва и смрт -

\section{(Вањка и Књига)}

Када су у питању приповетке у којима се као јунаци појављују деца, и Чеховљеве и Андрићеве приче о деци су другачије од прича на које су ученици навикли. Они руше мит о срећном и невином детињству. Детињство је приказано као сва остала раздобља живота, са пуно бола, патњи, страха, загонетки и чежњи: 
„Деца у Андрићевим причама одрастају без љубави, запостављена, сиромашна, не разумеју живот и не сналазе се у немилосрдном свету. Одрастање је тешко, оставља трагове и ожиљке” (Петровачки 2008: 258259).

Андрић „спада у писце који не идеализују детињство” (Милатовић 1996: 10), баш као и Чехов.

С тим у вези, компаративно проучавање Чеховљевог Вањке и Андрићеве Къиге отвара нове могућности наставне обраде. Обе приповетке у основи говоре о односу света одраслих и света деце и уједно су позив за хуманизацију тог односа. Оне су порука и за одрасле и за децу.

Чеховљева новела Вањка има двојаку природу: комичну и трагичну, топлу и хладну. Она са једне стране говори о љубави дечака према деди, а са друге стране о насиљу које над дечаком спроводе газда и газдарица код којих учи занат. Комичност и топлина избијају из сећања главног јунака. Трагично и тужно одлика је дечакове стварности. „Тужно писмо деди у село" (Мелетински 1997: 321) апел је једног дечака за помоћ, дечака уплашеног и изложеног неправдама и патњама, отргнутог из стварности и топлине дома. Тај дечак говори у име свих оних који су били или ће бити жртве насиља. Тема коју Чехов бира у модерним временима постаје све актуелнија. Једини глас који постоји у овој приповеци је глас дечака. Она друга страна, страна одраслих остаје нема.

Баш као и дечак Вањка, и дечак у Андрићевој приповеци Кюига проживљава трауму. За ову приповетку се иначе мисли да је ,једна од најбољих Андрићевих приповедака" (Бандић 1963: 155), као и да је управо она ,репрезентативна Андрићева приповетка за децу” (Илић 1999: 37). Оно што су обућар Аљахин и његова жена за Вањку, то је за Андрићевог дечака професор-библиотекар. Одрасли су и овде они који не чују, не примећују „оне ситне, невидљиве, а судбносне догађаје у којима се ломе душе тих малих људи, а које ми зовемо децом" (Андрић 2008: 224).

Обе приповетке ће на ученике васпитно деловати, јер их уче какви они не треба да буду као одрасли људи. С друге стране, оне су апел писаца за оплемењивањем односа одраслих и деце.

Осим тога наведене приповетке повезује и мотив писма. Док дечак Вањка пише писмо свом деди, Андрићев дечак чезне да добије писмо један и други писмо виде као спас. 
Писмом дечак Вањка моли деду да дође по њега у Москву и врати га на село. Писмо које пише на Бадње вече је дирљива и интимна исповест једног дечака. Испричана из дечје перспективе, а опет маестрално сликовита и сугестивна.

Дечак у Кьизи свакога дана на великој црној табли међу именима оних који имају писмо код служитеља тражи своје име:

„Дечак посматра, као увек, ту таблу и имена редом, а сазнање да за њега нема и не може да буде ништа, јер му нико не пише, осећа као нарочити и већ добро познат бол" (Андрић 2008: 224).

Када му се од неког имена учини да је његово, он:

„Види одмах у мислима писмо, право писмо, затворено, са маркама, поштанским жиговима и свим траговима даљине и путовања, са ни сам не зна каквим све порукама, важним, лепим и занимљивим. Шта све не може да садржи једно писмо? Само ко има среће да га добије" (Андрић 2008: 224).

Међутим, убрзо схвати да то ипак није његово име:

„Ни писма нема, ни поруке из даљине. Као што, на жалост, нема ничега лепог ни необичног ни узбудљивог, него само једноличан живот, без чуда и изненађења, саткан од простих и оскудних догађаја, неодређених и нејасних, а мучних и сувопарних дужности и обавеза" (Андрић 2008: 224).

У том тренутку Андрић одлази од мотива писма да би му се касније, на кратко, опет вратио, помињући да након што је "успешно" вратио књигу библиотекару, дечак таблу са именима срећних добитника писама није ни погледао.

Осим писма у још једном мотиву ова два дечака проналазе утеху - у мотиву молитве. Вања молећи деду, обећава му да ће Бога молити за њега док је жив, а након смрти молиће се за његову душу. Читава новела је заправо Вањкина молитва.

Дечак у Къизи, страхујући због казне која би могла да уследи након одлепљених корица књиге, потражио је спас у молитви:

„Шапутао би, заиста, све познате молитве, нечујно, дуго и усрдно. Са дланом на устима [...] упућивао је жарке речи право Богу и његовим 
свецима, који, као што се каже, могу да чине и већа чуда, и тражио да се раскоричена књига састави" (Андрић 2008: 227).

На крају је мотив смрти. Вањка у писмо деди каже: „узми ме одавде, иначе ћу умријети" (Чехов 1990: 253), док Андрићев дечак изможден страхом жели да умре:

„Да умрем - мислио је тада дечак у кревету, стегнутих вилица, сав згрчен да умрем сада одмах! Умрети значило би не морати поверавати се никоме, не чекати чуда која неће да дођу, не одговарати за оно што ниси крив, не морати никад више ступити пред оног риђег, подругљивог човека. То би значило да нестане мене, али са мном и књига, здравих, оштећених и поправљених, и библиотека и библиотекара, и одговорности, и страха од њих. Боже, дај да умрем” (Андрић 2008: 227).

Андрић овде говори о дечаковој „тешкој узнемирености која расте” (Тартаља 2010: 262). Ове реченице представљају „приповедачево потпуно преношење у душу и тело јунака све дотле док јунакова судбина не постане живо ткиво приче" (Тартаља 2010: 261).

Код Андрића побеђује живот, док Чехов оставља простора да читалац допише странице Вањкиног живота, јер „све док људи живе, нема могућег и коначног краја њиховим невољама, надама и сновима" (Набоков 2006: 95). „Новела се завршава нагло, у Чеховљевом маниру” (Жутић 2011 : 268). Он се често концентрише управо „на нагли новелистички обрт на крају приче” (Мелетински 1997: 320). „А како је тек завршавао своје приповетке? Неочекивано, нагло, остављајући читаоца да размишља...” (Новачић 2004: 40).

\section{6. МЕТОДИЧКИ ПРИСТУП}

Наставна обрада Чеховљеве новеле Вањка везује се за шести разред основне школе, док се Андрићева Къига обрађује у осмом разреду. Како ниједан Чеховљев текст није замишљен за обраду у осмом разреду, ево прилике да то надокнадимо враћајући се поново његовој Вањки, коју ћемо овај пут посматрати упоређујући је са Андрићевом Къигом.

Ученици ће бити подељени у пет група. Сви ученици добиће раније материјал за читање код куће. У питању је читање обе приповетке у целини. Прве четири групе чиниће ученици различитих нивоа знања и постигнућа. У 
петој групи налазиће се ученици који се добровољно јаве да пишу литерарни рад на тему: Чеховољево, Андрићево и моје детиьство, чиме се афирмише стваралачка настава.

\section{1. Истраживачки задаци}

\subsection{1. Прва група}

Опишите какво једно детињство треба да буде.

Пратите и упоредите мотив детињства у Чеховљевој приповеци Вањка и Андрићевој Къизи.

Упоредите Андрићев и Чеховљев мотив и ваш први одговор.

\subsection{2. Друга група}

Зашто се пишу писма?

Пратите и упоредите мотив писма у Чеховљевој приповеци Вањка и Андрићевој Кюизи.

Упоредите Андрићев и Чеховљев мотив и ваш први одговор.

\subsection{3. Трећа група}

Зашто се најчешће моли?

Пратите и упоредите мотив молитве у Чеховљевој приповеци Вањка и Андрићевој Кюизи.

Упоредите Андрићев и Чеховљев мотив и ваш први одговор.

\subsection{4. Четврта група}

Зашто неко пожели своју смрт?

Пратите и упоредите мотив смрти у Чеховљевој приповеци Вањка и Андрићевој Кюизи.

Упоредите Андрићев и Чеховљев мотив и ваш први одговор.

\subsection{5. Пета група}

Напишите литерарни рад на тему: Чеховљево, Андрићево и моје детињство. 


\section{7. МОТИВ ТУГЕ И УТЕХЕ}

\section{(Туга и О причи и причању)}

Беседа $O$ причи и причању „крије мноштво суштина о књижевности и стварању” (Петровачки 2008: 263). Она је „с разлогом ушла у читанке и дошла у ред широко познате есејистике" (Тартаља 2010: 257). У њој Андрић износи своја размишљања о позицији уметности и уметника. Прича је у њој представљена као метафора књижевности, али и читаве уметности. Све што је међу људима током векова исприповедано слило се у једну бескрајну причу.

Андрић повезује приче из древних и модерних времена, јер све причају исто - о судбини човековој: „Основни је мотив причања вазда увек исти: човекова судбина” (Тартаља 2010: 261).

Сврха приче је да победи смрти, па је она нешто као „анти-судбина” (Тартаља 2010: 257), да помогне човеку да се нађе и снађе, те има „своју васпитачко-андрагошку мисију” (Тартаља 2010: 257). Приповедач говори у име свих оних који нису умели или нису стигли да говоре, „у име мноштва” (Тартаља 258). Он њом лечи своје страхове, прича самом себи (Тартаља 2010: 259). У причи је садржана права историја човечанства, а то је њена „сазнајна компонента” (Тартаља 2010: 260). Прича нас учи: како Бити човек.

„Бити човек, рођен без свог знања и без своје воље, бачен у океан постојања. Морати пливати. Постојати. Носити идентитет. Издржати атмосферски притисак свега око себе, све сударе, непредвидљиве и непредвиђене, поступке своје и туђе, који понајчешће нису по мери наших снага. А поврх свега треба још издржати и своју мисао о свему томе. Укратко: бити човек” (Андрић 1976: 337).

У контексту ових Андрићевих мисли могуће је посматрати и Чеховљеву новелу Туга. Већ у самом епиграму „Коме да искажем јад свој”, алудира се на потребу да се прича исприча. Тако испричана она ће олакшати душу.

„Патња постаје мања ако се неком исприча. Човеку - патнику је лакше кад прича о својим и туђим патњама. Можда се бола човек једино може ослободити причом?! Зато је она исцелитељска и спасоносна" (Петровачки 2008: 260). 
Јона Потапов, главни лик ове приповетке је онај који нас учи како бити човек. Он плива, иако му удари таласа живота нимало не пријају. Међутим, у том океану постојања, једино он има име. Остали ликови су типизирани, они немају име, они су атрибути - униформа, дугоња, грбавко они су људи, без имена, без душе. У том таквом свету нема за његу утехе:

„Али маса жури не примећујући ни њега ни његову тугу... Туга, голема, бескрајна... Да пукну Јонине груди и да се из њих излије туга, свет би поплавила, а ипак се не види" (Чехов 1990: 163).

Међутим, његова жеља да неком опише своју бол не престаје: „неће ли се између хиљаде људи наћи бар један једини који би хтео да чује за његов бол” (Чехов 1990: 163). На крају, Јона је своју причу испричао кобилици, јер:

„скоро ће бити седам дана како му је син умро, а он још ни с ким није могао да поразговара. Јер треба поразговарати паметно, полагано, од срца. Треба испричати како се син разболео, како се мучио, шта је пред смрт рекао, шта је говорио, како је умро... Треба описати сахрану и одлазак у болницу по одело покојниково. У селу остала кћерчица Анисја... И о њој треба поразговарати. Зар би се мало шта имало казати и поразговарати?” (Чехов 1990: 164).

Чехов Јонину причу само започиње. Завршавају је три тачке. Оставља простор читаоцу да доприча Јонаину бол, да га утеши. Осим тога, оставља простор за нове боли и причу као утеху.

\section{1. Туга и На други дан Божића}

Чеховљеву новелу Туга и Андрићеву приповетку На други дан Божића повезује исти библијски подтекст. Наиме, реч је о библијској параболи о убогом Лазару из Јеванђеља по Луки, која представља Христову проповед о богатом и охолом човеку који је провео живот у весељу и изобиљу. Испред његових врата лежао је болестан сиромах Лазар, чекајући господареву милостињу. После смрти су промењене улоге: сиромах је отишао у рај, а богаташ у пакао. Мучећи се у вечном огњу, некадашњи господар моли праоца Аврама да пошаље Лазара да му олакша муке, а Аврам рече: „Синко, сјети се ти си примио добра своја у животу своме, а 
тако и Лазар зла: сад пак он се тјеши, а ти се мучиш" (Јеванђеље по Луки, 16, 25).

Чеховљев главни лик носи име Јона Потапов. Он је једини, који у новели има име. Остали ликови су типизирани, они немају име. Јонино име је знаковито, име са библијском семантиком. Наиме, име се повезује са пророком Јоном из Кьиге о Јони у Старом завету, а презиме са легендом о Потопу. У имену се препознаје осим имена Јона и име Ноја, чиме се семантика Потопа удвостручује. С друге стране, Андрићев главни лик нема име, он је само конзул. То сигурно није случајно. Он носи име које има значење само на овом свету и одређује читав његов живот. Та исти конзул ће постати безимен на оном свету, баш као и богаташ из поменуте параболе. Мото Чеховљеве новеле успоставља интертекстуалну везу са стиховима из Давидових Псалама у коме псалмопојац тражи помоћ у жалости или невољи. Поука ове јеванђелске параболе послужила је Андрићу да напише мајсторски компоновану причу о кривици која у контексту Јеванђеља поприма метафизичке димензије. На други дан Божића је модернизована парабола уграђена у реалистички сиже о ревносном конзулу, грађена по мотивима приче о убогом Лазару. Врхунац приче је у епилогу, који садржи поуку до које долази сам протагониста у кошмарном сновиђењу. Долази до неочекиване измене улога и перспективе: конзул се нашао пред вратима страног конзулата чекајући ред са ужасом сазнања да је остао без новца и пасоша. Он у сну осећа на свој кожи сопствену окрутност.

С друге стране, Јона је убоги Лазар. Он осећа на својој кожи окрутност људи као што је конзул, али он не сања, то је његова стварност. Он наилази на неразумевање људи за његову бол. Међутим остаје нада да је он тај који ће се као убоги Лазар тешити у рају, кога ће као Јону Бог ослободити из утобе кита и који ће се као Ној спасити Потопа, као и да ће његове молитве као и Давидове речи стићи на праву адресу. Ово је још једна потврда Чеховљевог дара да једног малог, обичног човека уздигне на пијадестал великих јеврејских мудраца и пророка.

\section{8. МЕТОДИЧКИ ПРИСТУП}

Чеховљева новела Туга и Андрићева беседа $O$ причи и причању налазе се у наставном програму за први разред средње школе. Поред њих овом наставном обрадом ученици се уводе у свет Библије, која се такође 
обрађује у овом разреду. Ученици ће бити подељени у четири групе. Свака групе ће две недеље раније добити истраживачке задатке, као и материјал за читање код куће.

Након наставне обраде, ученици ће резултате свог истраживања представити на јавном часу, коме ће присуствовати други наставници и ученици школе. Тиме ће бити промовисана истраживачка наставна метода, али и компаративна и интертекстуална наставна метода, које отварају нове просторе модерне и креативне наставе.

\section{1. Истраживачки задаци}

\subsection{1. Прва група}

Пратите мотив туге у Чеховољевој новели Туга.

Има ли утехе у овој новели?

\subsection{2. Друга група}

Протумачи мисао из Андрићеве беседе О причи и причању:

„Бити човек, рођен без свог знања и без своје воље, бачен у океан постојања. Морати пливати. Постојати. Носити идентитет. Издржати атмосферски притисак свега око себе, све сударе, непредвидљиве и непредвиђене, поступке своје и туђе, који понајчешће нису по мери наших снага. А поврх свега треба још издржати и своју мисао о свему томе. Укратко: бити човек”.

Повежи ову мисао са ликом Јоне Потапова из Чеховљеве новеле Tyга.

\subsection{3. Трећа група}

Шта о улози приче (књижевности, уметности) Андрић каже у својој беседи $О$ причи и причању?

Шта прича доноси Јони Потапову у Чеховољевој новели Туга? Повежите одговор са Андрићевом беседом.

\subsection{4. Четврта група}

Прочитај параболу о убогом Лазару из Јеванђеља по Луки.

Прочитај Андрићеву приповетку На други дан Божића. 
Повежи Јону Потапова из Чеховљеве новеле Туга и конзула из Андрићеве приповетке На други дан Божића са ликовима из библијске параболе, убогим Лазаром и богатим господаром.

\section{9. ПРИМЕРИ МУЛТИМЕДИЈАЛНИХ ОБРАДА}

Мултимедијски приступ у настави „омогућава далекосежну објективизацију различитих ситуација учења и поучавања” (Педагошки лексикон 1996: 305), али и „примену различитих наставних облика, поступака и метода, диференцијацију и индивидуализацију, рационализацију и оптимализацију рада и учења и остваривање ефикаснијих резултата" (Педагошки лексикон 1996: 304). Представља један од модерних приступа настави, према којима ученик није објекат поучавања, већ субјекат наставног процеса. Наставник не поучава, него усмерава наставни процес у коме ученици освајају знања. Све то „пружа више слободе ученицима, али и прилике за самостални и истраживачки рад, као и задовољство у учењу” (Сучевић 2010: 118).

Србија је окружење у коме је дуго владао традиционални образац образовања и опредељење за фронтални облик рада без учешћа иновација. Учење је било механичко, без истраживачког и пројекатског рада. Све то скупа доноси знање које је неприменљиво у свакодневном животу. Ученике треба усмерити на решавање проблемских задатака, како би научено могли повезати са животним ситуацијама.

Мултимедијални приступ у настави је иновативни модел, који „окрепљује чула, очигледније приказује садржаје и самим тим омогућава трајније памћење” (Сучевић 2010: 118). Доводи до рационализације и активизације. Међутим, „захтева и комплексна знања и искуства, изискује време, енергију и стрпљење за примену” (Сучевић 2010: 121).

Јасно је да мултимедиј нема решење за све проблеме савременог наставног процеса. Разлог његове тешке применљивости је и неповољан положај просвете и школства у Србији. С друге стране, нису ни сви наставни садржаји погодни за овакву наставну обраду. Деца понекад изискују и близак контакт са наставником. Стога треба пронаћи „разумну границу у употреби медија" (Сучевић 2010: 125).

Ослушкивањем потреба нових генерација, управо се мултимедија 164 намеће се као незаобилазна: 
„Ученици данас испољавају мање афинитета према прописаној лектири, а пажњу им заокупљају бројне компјутерске игрице и интернет, стога на наставнику књижевности стоји и обавеза да осавремени наставу и у њу уведе модерну технологију” (Стакић 2002: 54).

Иако су препреке, када је у питању увођење мултимедијалних средстава у наставу бројне, почев од техничке неопремљености школа, често информатичке неписмености наставника, али и времена и труда које је потребно утрошити како би мултимедија остварила своје највише домете, свакако треба покушати. Временом, све препреке постају небитне, ситне, наспрам резултата који се постижу. Често су ученици ти који ће у области мултимедије можда показати боље знање од својих наставника, али суштина наставе и треба да буде управо у партнерском раду наставника и ученика.

У овом делу рада биће понуђени методички модели свих до сада наведених тема, са акцентом на мултимедијалној обради. Већина модела замишљена је у виду ученичких пројеката, са циљем промоције стваралаштва ученика. Коришћене су предности и могућности аудио- и видео-записа, анимација, презентација, сајта www.kahoot.it ${ }^{4}$, али и Google Docs $^{5}$. У стручној литератури се препоручују:

„специјални, синтетски часови књижевности, панорамски час, радионичарски облици рада, књижевно-музички, књижевно-сценски, књижевно-филмски часови, мултидисциплинарни, такмичења у драматизовању текстова, изради сценарија, рецитовању, вежбању сценског говора, беседништву итд., тј. све више се инсистира на реализацији едукативних радионица као доминантним обликом активног учења/наставе” (Карановић, Јокић 2014: 6).

У том правцу крећу се и наставне обраде које следе.

Повезивање Чеховљевих и Андрићевих приповедака отвара бројне могућности мултимедијалне обраде. Једна од идеја јесте да се организује мала фотографска колонија на тему Трагом Андрићевих и Чеховљевљих лиц̧а,

\footnotetext{
${ }^{4}$ Kahoot je једноставан и иновативан веб-алат намењен изради и игрању квизова. Овај интерактивни алат користи елементе учења кроз игру. Код ученика подстиче такмичарски дух, те тако повећава мотивацију. Најпре треба на веб-страници www.create.kahoot.it направити квиз, који је касније могуће радити на веб-страници www.kahoot.it.

${ }^{5}$ Google Docs нам омогућава да пишемо, уносимо измене и сарађујемо где год да смо и то бесплатно. Google Docs свима омогућавају да истовремено раде на истом документу.
} 
стаза и предела. Како је Сава Шумановић један од наших најпознатих сликара, могуће је у истраживање укључити и његова дела. Наиме, ученици би након читања задатих приповедака, у току једномесечног истраживања, покушали да пронађу личност или пејзаж који би се могао повезати са поменутим делима, али и да то фотографишу. Након тога, на изложби фотографија свако од ученика би укратко представио своју фотографију. На крају, жири који би чинили локални фотограф, сликар и наставник Ликовне културе прогласили би победника, а најуспелије фотографије биле би штампане у виду брошуре.

Обрада Приче о кмету Симану, Ђорђа Ђорђевића и Чиновникове смрти замишљена је као драмска изведба на тему Разговор Симана, Ђорђа и Чиновника - Могло је другачије:

„Најпогоднији начин за креативно поигравање са књижевним текстом по мишљењу методичара представља примена основних поставки сценске уметности (различити облици драматизације као што су слободне драмске импровизације, пантомимске вежбе, глума на задати лик и тему, игроказ и сл.), те се стога залажу за увођење што више оваквих садржаја у савремене наставне планове и програме језика и књижевности" (Карановић, Јокић 2014: 67).

Уз помоћ наставника Информатике у виду кратке видео-анимације ученици би могли представили ову тему. Циљ овог филма - указати ученицима на могућности креативног решавања проблема. У изради филма, поред ученика, наставника Српског језика и Информатике, учествовали би и педагог и психолог школе.

Поређење Андрићеве Книге и Чеховљеве припоеветке Вањка замишљено је као симулација ТВ емисије на тему Чеховљево, Андрићево и моје детињство. Како бројне друштвене мреже пружају могућност директног преноса, уз подршку родитеља ученика, ту могућност би било могуће искористити. Учионица би постала мали ТВ студио: камерман, водитељ, публика, сценографија и гости (Вањка, Дечак и неколико ученика). Свако од гостију говорио би о изазовима свог детињства, проблемима на које наилази. Водитељ и публика би постављали питања. Циљ ове емисије јесте емотивно укључивање одраслих у решавање проблема ученика. На крају, педагог и психолог школе, дали би кратки резиме емисије, као и стручне савете, како се поменути проблеми могу превазићи. 
Осим тога, уз могућности Google Open Documenta ученици би заједно писали Писмо Чеховљевом Вањки и Андрићевом дечаку. Један од ученика кроз кратку мултимедијалну презентацију подсећа остале ученике о писму као форми изражавања како приватном тако и службеном. Ученици пишу писмо истовремено, али свако од њих то ради посебно, на свом рачунару, у кабинету. На крају, на следећем часу, који би уједно био припрема за писмени задатак, исправили би правописне и граматичке грешке и стилски обликовали текст, користећи пројектор и тзв. паметну таблу. Ученици се овим путем упознају са могућностима модерне технологије, али и заједно стварају уметнички текст.

Како су оба дечака усамљена, док Вањка пише писмо не знајући адресу, Андрићев дечак жељно прижељкује писмо које не стиже, ученици би могли покренути хуманитарну акцију. Најпре, ученици треба да направе мало истраживање на интернету у коме би пронашли некога коме би њихово писмо измамило осмех. Њихов задатак био би да напишу писмо, а у школи би након тога покренули акцију Слаткиш за осмех. Прикупљање слаткиша могло би да се одвија у току школских одмора, али и на организованој школској журци или спортској утакмици на којој би против екипе ученика школе играли наставници школе. За организацију ученици би могли да користе бројне могућности друштвених мрежа и тако квалитетно утроше време које проводе испред рачунара и сличних уређаја. Улазнице за журку или утакмицу били би слаткиши, који би заједно са писмом у нечији усамљени живот донели осмех. Ово је прави начин да се књижевност повеже са животом, јер има ли ишта лепше од ХУМАНОСТИ?!

Чеховљева приповетка Туга говори о трагичној судбини Јоне Потапова. У виду презентације, видео-анимације или кратког видео-записа ученици би приказали Јонину судбину. Све то пратиле би одговарајуће мисли из Андрићеве Беседе. Ученици добровољци могли би да у видеозапису говоре о својој тузи или тузу својих блиских рођака и пријатеља. Након тога било би пожељно организовати радионицу о могућностима за превазилажење туге, али и повећању емпатије на туђу тугу. Могуће је у оквиру затворене групе на једној од друштвених мрежа, поставити видеозаписе и организовати дебату. 


\section{0. ЗАКЉУЧАК}

Компаративна анализа Чеховљевих и Андрићевих приповедака вишеструко иновира наставу књижевности. Најпре се њом у наставну праксу уводе компаративна и интертекстуална метода, које у средишту интересовања када је у питању наука о књижевности како код нас тако и у свету. Поред тога, промовише се проблемско-стваралачки методички систем, као и истраживачка наставна метода, чији је заједнички циљ подстицање стваралачке способности ученика и креативне улоге наставника у васпитно-образовном процесу. Наставник постаје мотиватор и организатор, а у средишту наставе су ученик и књижевно дело. Анализом се, такође, изједначава разлика између Андрића, као једаног од најзаступљенијих писаца у наставним програмима за основну и средњу школу и помало запостављеног Чехова. Уводе се нове приповетке, које до сада нису биле заступљене у наставним програмима. Осим тога, проширује се круг писаца чије се дело доводи у везу са Андрићевим. Ту везу на нивоу поетике уочио је и изложио у свом раду Милан Ђурчинов, те је његов рад на известан начин и био камен темељац овој анализи, њена иницијална мотивација. На крају, понуђени су примери мултимедијалних обрада наведених тема, са циљем осавремењавања наставе.

Повезивањем приповедака наведених писаца са Библијом, књигом над књигама. „Древне библијске параболе уче нас да је прва прича покренута љубављу” (Радуловић 2003: 152). Љубављу је покренута и ова анализа, љубављу према књизи, према позиву наставника, према бескрајној причи Библије, Чехова, Андрића, љубављу и жељом да се та љубав пренесе даље и освоји неке нове, младе универзуме и космосе: „Може се пуно тога урадити само треба упалити пламичак у срцима младих".

За крај, остављам речи Весне Радуловић ${ }^{7}$, која је у једном интервјуу на питање шта је кључ добре инклузивне праксе између осталог одговорила: „Довољно је само раширити руке”.

6 Интервју са Даринком Матић-Маровић поводом Седмојулске награде, Илустрована политика, 8. јули 1986, стр. 27.

7 Весна Радуловић је чланица мреже за подршку инклузивном образовању и просветна саветница Школске управе Нови Сад.

8 Интервју се налази на интернет адреси http://teaching-academy.com/intervju-sa-vesnomradulovic/. 
применити и на целокупну наставну праксу. Стога, ова анализа су моје с љубављу раширене руке.

\section{ЛИТЕРАТУРА}

Андрић, И. (1976). Есеји и критике. Сарајево: Свјетлост.

Андрић, И. (2008). Сабране приповетке. Београд: Завод за издавање уџбеника.

Библија или Свето писмо Старога и Новога завјета (1993). Београд: Британско и инострано библијско друштво.

Бандић, М. (1991). “Октобар-март”. Кюижевност 46: 621-623.

Ђурчинов, М. (1991). “Андрић и Чехов”. Книжевност 46: 607-612.

Жутић, Д. (2011). “Антон Павлович Чехов у наставном прочавању”. Славистика 15: 267-276.

Илић, П. (1999). У свету Андрићеве уметности. Нови Сад: Змај.

Илић, П., Гајић, О., Маљковић, М., Кошничар С. (2011). Читањем ка стварању стварањем ка читању. Нови Сад: Градска библиотека - Прометеј.

Калезић, С. (2006). “Однос истока и запада у дјелу Ива Андрића”, у Дјело Ива Андрића у новом миленијуму : зборник радова, ур. Ј. Вучетић (Нови Сад: Змај, Херцег Нови: Просвјета): 116-141.

Карановић, 3., Јокић, J. (2014) “Криза читања и (могући) начини њеног превладавања у настави“, у Мотивачија ученика за читање књижевних дела, ур. Наташа Половина (Нови Сад: Филозофски факултет): 5-8.

Марковић, С. Ж. (2010). “Историјски дух у књижевном делу Иве Андрића”, у Прилози језичком и књижевном образовану. предавања са семинара за наставнике и професоре српског језика и књижевности : 100 година друштва II, ур. Б. Милић и В. Брборић (Београд : Друштво за српски језик и књижевност Србије): 109-116.

Мелетински, Ј. (1997). Историјска поетика новеле. Нови Сад: Матица српска.

Милатовић, В. (1996). Кюижевно дело Иве Андрића у настави. Београд: Завод за уџбенике и наставна средства.

Набоков, В. (2006). Есеји. Београд: ННК Интернационал.

Николић, М. (2009). Методика наставе српског језика и књижевности. Београд: Завод за уџбенике и наставна средства.

Новачић, А. (2004). Досије Чехов. Београд: Zepter book world.

Педагошки лексикон (1996). Ур. П. Пијановић. Београд: Завод за уџбенике и наставна средства.

Петровачки, Љ. (2008). Методика истраживања у настави српског језика и књижевности. Нови Сад: Филозофски факултет. 
Петровачки Љ., Штасни Г. (2010). Методички системи у настави српског језика и кьижевности. Нови Сад: Филозофски факултет.

Радуловић, О. (2003). Лист небеске књиге. Нови Сад: Змај.

Радуловић, О. (2007). Речи са чистих усана, Београд: Друштво за српски језик и књижевност.

Стакић, М. (2002). Стручне методе у настави књижевности. Чачак: Легенда.

Сучевић, В. (2010). “Обрада наставних садржаја применом модела мултимедијалних презентација”. Речи 3: 117-128.

Showalter, E. (2010). Teaching literature. Malden (MA) : Blackwell.

Тартаља, И. (2010). “Андрићева беседа о причи и причању”, у Прилози језичком и књижевном образовању. предавања са семинара за наставнике и професоре српског језика и књижевности : 100 година друштва I, ур. Б. Милић и В. Брборић (Београд : Друштво за српски језик и књижевност Србије): 257-262.

Чехов, А. П. (1990). Сабрана дела. Приповетке. Београд: Југославија публик, Чаковец: Зрински.

Jovana Davidović

\section{ANDRIĆ AND CHEKOV IN THE TEACHING PROCESS}

\section{Summary}

Dealing with an intertextual connection in the stories of Anton Pavlovic Chekhov and Ivo Andrić, this paper extends this relationship. The aim is to show the intertextual links in the stories of Chekhov and Andrić in the context of male characters. The comparison is based on the following motives: rebellion, fear, caution, pettiness, childhood, letter, prayer, death, grief, consolation. In addition, some of these motives are connected with the Biblical subtext. The classwork also includes multimedia, which undoubtedly presents an important factor of successful teaching in contemporary education. As such, these stories are a good starting point for the methodical processing, which is in the spirit of the research teaching method, where students become familiar with the comparative literary method. The paper is designed as an incentive for the creation and modernization of the subject Serbian Language and Literature, with the aim to emphasize the principle of scientific approach in the contemporary teaching context and encourage active and creative reading. Through the application of contemporary methodical findings, this paper fights against every scheme, stereotype and rote learning, being bound by the artistic essence of literature. This way has achieved the most important goal of teaching literature - creating love for the book. Such teaching processing aims to help to overcome the reading crisis, certainly one of the biggest modern problems. The comparison of 
Chekhov's and Andrić's work provides an opportunity to mutually illuminate the beauty and complexity of their work and innovate teaching literature. The aim is to show the comparative links in the stories by Chekhov and Andric and expand the circle of writers with whom Andrić's work corresponds.

Keywords: short story, essay, motive, character, comparative method, intertextuality, Biblical subtext, teaching methods, multimedia.

Primljeno: 10.5.2017. Prihvaćeno: 15.10 .2017$. 